\title{
Persistence of Phytophthora ramorum in Soil Mix and Roots of Nursery Ornamentals
}

Nina Shishkoff, Research Scientist, ARS/USDA, Foreign Disease/Weed Science Research Unit. Frederick, MD 21702

\begin{abstract}
Shishkoff, N. 2007. Persistence of Phytophthora ramorum in soil mix and roots of nursery ornamentals. Plant Dis. 91:1245-1249.

Although most Phytophthora species have a soilborne phase that is crucial for infection of roots and for survival away from the host, the details of the soil phase of Phytophthora ramorum are not yet fully understood. As mycelium ages, it becomes resistant to sterilization by acidic electrolyzed water (AEW), a product of the electrolysis which can be used as a disinfectant. Colonies of $P$. ramorum could be recovered from moist potting mix or sand for many months, whether buried as infected plant leaf tissue or as mycelium bearing chlamydospores, and the buried material was also resistant to treatment by AEW. There was no significant difference in recovery over time among treatments (sand or potting mix; infected plant tissue or mycelium); after approximately a year, colonies could be recovered at 0.8 to $14.3 \%$. When excised roots were inoculated with $P$. ramorum sporangia and buried in mesh bags in potting mix, the pathogen was recovered from buried roots for at least 8 to 11 months, but it was not clear whether it was surviving as mycelium or chlamydospores. The roots of living plants of Acer macrophyllum, Buxus sempervirens, Camellia oleifera, C. sinensis, C. sasanqua, Lonicera hispidula, Taxus baccata, Umbellularia californica, Vaccinium macrocarpon, Viburnum davidii, V. tinus, V. $\times$ pragense, Rhododendron 'Gloria', and Syringa vulgaris were drenched with a sporangial solution of $P$. ramorum and incubated for a month; the pathogen could be recovered from roots of all plants except those of Buxus sempervirens and Lonicera hispidula. Recovery on selective agar medium ( $\mathrm{P}_{5} \mathrm{ARP}$ ) was from both washed and surface-sterilized roots, suggesting that the roots were internally infected. When chlamydospores were placed near roots and observed directly, they were seen to germinate, forming sporangia. Nearby roots became infected, the tips covered with sporangia. Therefore, $P$. ramorum appears to have a soil phase, at least under greenhouse and nursery conditions.
\end{abstract}

Additional keywords: sudden oak death

Phytophthora ramorum causes stem cankers on oaks and foliar lesions and stem dieback on a number of plants (7). It was first observed in the 1990s in California coastal forests and in Europe on nursery stock (19). Although the distribution of $P$. ramorum in U.S. forests is currently limited to parts of California and Oregon, there is potential for spread with the movement of water, soil, plants, and plant products. By the end of 2004, infected containerized ornamentals were inadvertently shipped from California to at least 40 states (18), leading to the instigation of an Emergency Federal Order, which placed restrictions on the movement of host plants shipped out of California, Oregon, and Washington (2). To make such a quarantine

Corresponding author: N. Shishkoff

E-mail: Nina.Shishkoff@ars.usda.gov

Accepted for publication 17 April 2007.

doi:10.1094/PDIS-91-10-1245

This article is in the public domain and not copyrightable. It may be freely reprinted with customary crediting of the source. The American Phytopathological Society, 2007. effective, it is essential that the life cycle of the organism be clearly understood.

Zoospores and sporangia infect the aboveground portions of plants, but what happens in the soil is not well understood. In forests, $P$. ramorum has been shown to spread in soil along hiking trails (8), but it isn't clear in what form the pathogen survives and is spread. $P$. ramorum has been shown to survive in buried leaf tissue in forest soils for up to 24 weeks (9). Preliminary data indicated that $P$. ramorum would infect roots under laboratory or greenhouse conditions $(6,12,16,17)$, and it has recently been observed infecting the roots of tanoaks under natural conditions (15).

In addition to sporangia, $P$. ramorum produces chlamydospores, which are structures that are associated with long-term survival in soil in other Phytophthora species (10). Phytophthora cinnamomi is 2 chlamydospore-forming species that survives in soil, dead root pieces, or living root systems. It also has a wide host range and is a common pathogen in containerized nurseries. When it was introduced to Australian forests in the 1920 s, it proved to be one of the most destructive pathogens ever documented (14), and when it was introduced to the southern United States sometime in the late $1800 \mathrm{~s}$, it killed off chestnuts in the southern part of their range, chestnut blight removing the rest (1). It persists today as one of the most common Phytophthora species encountered in eastern forest soils (3).

The objective of this paper was to examine the soil phase of $P$. ramorum in containerized ornamentals, including the recovery of the pathogen after burial in potting mix and sand under greenhouse conditions and the ability of the organism to colonize living and dead roots of host plants. Better understanding of the pathogen might lead to better detection and eradication.

\section{MATERIALS AND METHODS}

Isolate. $P$. ramorum isolate (5-C) used in these experiments was originally recovered from Camellia sasanqua 'Bonanza' in California in 2003. It was maintained in sterile water culture or on $\mathrm{P}_{5} \mathrm{ARP}$ (see below) and inoculated onto and reisolated from Rhododendron or Camellia every 6 months to maintain pathogenicity. To determine percent recovery during experiments, chlamydospores and plant parts were plated on pimaricin-ampicillinrifampicin-PCNB agar selective medium ( $\left.\mathrm{P}_{5} \mathrm{ARP}\right)(11)$.

The culture is maintained at $-80^{\circ} \mathrm{C}$ as part of the international collection of plant pathogens at the National Cancer Institute's Central Repository in Frederick, MD.

Production of chlamydospores. Chlamydospores were produced within leaf tissue or as part of the mycelium produced in sterile water culture. This material was used to study the survival of $P$. ramorum in potting mix and in experiments where they were exposed to acidic electrolyzed water. Chlamydospores in tissue were produced in camellia plants by immersing foliage in a sporangial suspension (approximately 2,000 sporangia/ml water) and then incubating the plants in a dew chamber for 4 days at $20^{\circ} \mathrm{C}$. Symptomatic leaves were removed, washed, and placed in a plastic bag lined with a moist paper towel and incubated in the dark at $20^{\circ} \mathrm{C}$ for 3 weeks, until chlamydospores were clearly visible within leaf tissue when viewed with a zoom dissecting microscope at 20 to $60 x$. Disks were then cut from tissue using a cork borer (10 $\mathrm{mm}$ diameter) for burial in mesh bags. Chlamydospores and myce- 
lium were produced in sterile water culture by inoculating an autoclaved rye seed in a vial containing $4 \mathrm{ml}$ of sterile water with a plug of colonized agar and incubating at $20^{\circ} \mathrm{C}$ in the dark for different amounts of time up to 345 days (for experiments with acidic electrolyzed water, below) or for 3 weeks at $20^{\circ} \mathrm{C}$ (for burial in mesh bags, below).

Surface sterilization with acidic electrolyzed water (AEW). AEW is a product of the electrolysis of a dilute solution of sodium chloride, which can be used as a disinfectant. It has been used to study the behavior of persistent fungal structures such as teliospores (5). The AEW used in this study had a $\mathrm{pH}$ of 2.5 to 2.8 and oxidation/reduction potential of approximately $1,130 \mathrm{mV}$. Mycelium was produced in sterile water culture (11 vials total) and incubated for different amounts of time (6 days to 345 days). For treatment, mycelium from each vial was divided into six pieces, and pieces were submerged for 0 , $5,10,20,30$, or $40 \mathrm{~min}$ in AEW, then rinsed in distilled water. Each piece of treated mycelium was dragged through water agar to dislodge chlamydospores; cleanly detached chlamydospores were then individually plated on $\mathrm{P}_{5} \mathrm{ARP}$ media (approximately 80 chlamydospores per treatment). Plates were observed for 1 to 2 weeks using a dissecting microscope with dark field illumination to observe germination of chlamydospores. The percent colony formation in each treatment was recorded. In addition, surplus chlamy- dospores from mesh bag experiments (11 samples; see below) were treated with AEW in the same manner and plated (approximately 90 chlamydospores per treatment), and the percent colony formation was recorded.

Buried mesh bag experiments. Leaf disks from $P$. ramorum-infected leaves (two per bag) or mycelium from sterile water culture were placed in small $(40 \times$ $40 \mathrm{~mm}$ ) mesh bags, except for material used in the time zero sample. Bags consisted of two panels of $52 \mathrm{u}$-mesh opening Spectramesh woven filters (Spectrum Laboratories, Inc., Laguna Hills, CA) held together on three sides by waterproof tile sealant and, after filling, sealed on the fourth with duct tape. Each bag was then buried $4 \mathrm{~cm}$ deep in a 150 -cm-diameter pot containing potting mix or pure river sand for a total of 28 to 32 pots, depending on the experiment. Potting mix was intended for ericaceous plants and consisted of 5 parts standard mix (Promix BX 30\%, Leafgro $30 \%$, coarse perlite $16 \%$, coarse vermiculite $8 \%$, peat moss $8 \%$, sand $8 \%$, plus 10-10-10 fertilizer, lime, trace minerals, and wetting agent), 3 parts fine pine bark, and 2 parts river sand; $\mathrm{pH}$ was 5.27 in $0.01 \mathrm{M} \mathrm{CaCl}_{2}$. Pots were incubated under greenhouse conditions $\left(25 \pm 3^{\circ} \mathrm{C}\right.$ year-round) and watered using overhead irrigation triggered by a leaf hygrometer set to go off when the sensor dried (this varied with the weather, being more frequent on hot, dry days, but in general being triggered once an hour for $10 \mathrm{~s}$ ).

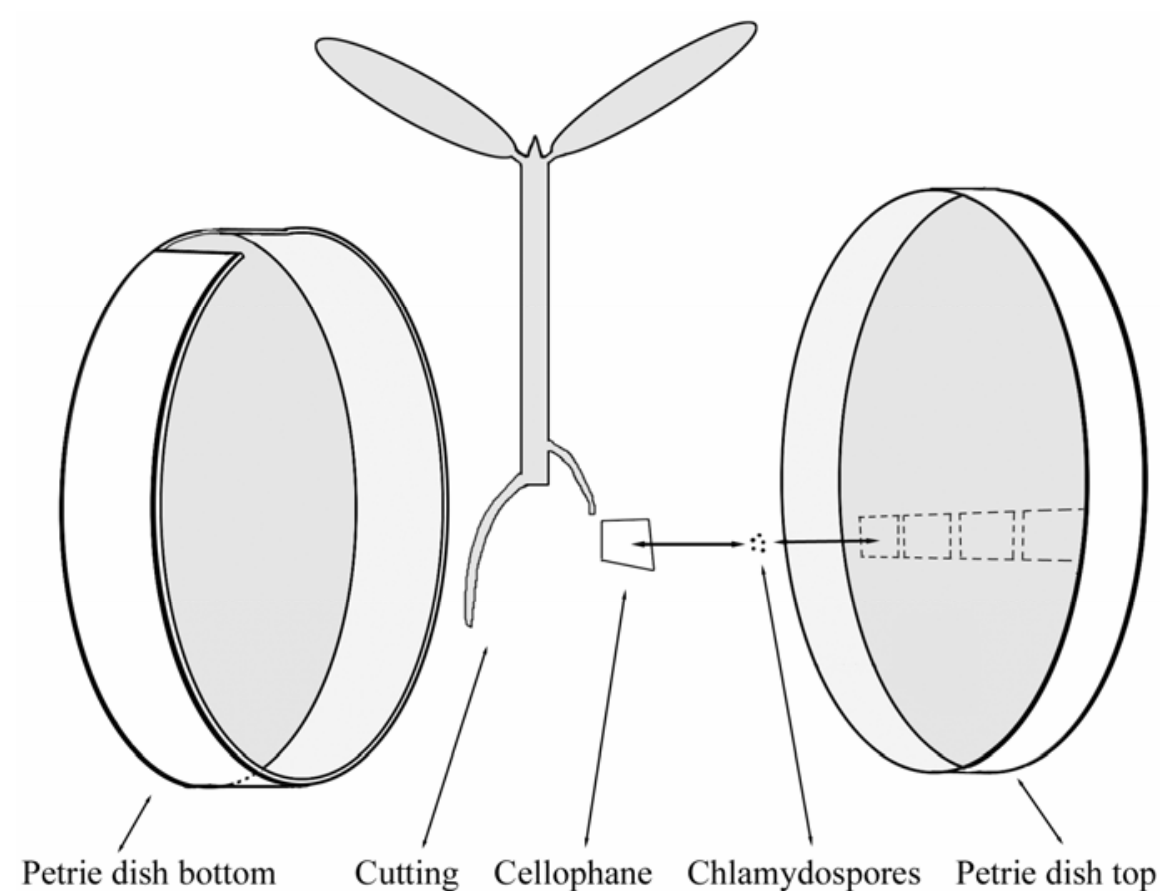

Petrie dish bottom Cutting Cellophane Chlamydospores Petrie dish top

Fig. 1. A schematic drawing of a petri dish used as a "rhizotron" to observe infection by Phytophthora ramorum in Viburnum cuttings. A small portion of the rim on the bottom plate was removed to allow the stem of the cutting to protrude, while roots developed in turface within the dish. Chlamydospores were placed against the wall of the petri dish and secured with a small piece of cellophane. Chlamydospore germination and root growth and infection could then be observed through the clear plastic wall using a dissecting microscope.

Duplicate mesh bags (the contents of two pots) per treatment were removed at approximately 2-month intervals and carefully opened. After incubation in sand or potting mix, chlamydospores from sterile water culture were now loose in the mesh bag and could be picked up on the tip of a dissecting needle and plated individually on $\mathrm{P}_{5} \mathrm{ARP}$ media; chlamydospores in leaf disks were teased from decayed plant tissue and plated. Approximately 250 chlamydospores per mesh bag were plated (therefore, 500 per treatment). After incubation in a dark incubator at $20^{\circ} \mathrm{C}$, plates were observed periodically for at least 2 weeks using a dissecting microscope with dark field illumination to observe germination of chlamydospores and development of the characteristic mycelium of $P$. ramorum; the number of germinating chlamydospores was recorded. The experiment was repeated once.

Survival in buried root pieces. In two trials, small feeder roots were detached from one plant each of three species (Viburnum davidii, V. $\times$ pragense, and Syringa vulgaris) and placed in a suspension $(4,000$ sporangia/ml $)$ of sporangia for 4 days. At the end of this period, they were symptomless and showed no signs of infection. Roots were then washed and some were used as the time zero samples; the remainder were placed in mesh bags (approximately 50 roots per bag), which were buried $5 \mathrm{~cm}$ down in potting mix in 150$\mathrm{cm}$-diameter pots. Three bags, one for each species, were placed in each pot, for a total of 12 pots in the first trial and 10 pots in the second. Pots were incubated under greenhouse conditions with overhead irrigation using a leaf hygrometer at temperatures of $25 \pm 3^{\circ} \mathrm{C}$. In the first experiments, bags were sampled at 50,101, 185, 255, and 341 days after burial, and in the second, at 39, 89, 147, and 242 days after burial. At each sampling, duplicate bags for each plant species were removed (i.e., the contents of two pots), and the root pieces (approximately 50 pieces) were plated on selective media. The number of roots giving rise to colonies of $P$. ramorum was recorded.

Root infection. Five to 15 cuttings ( 1 to 6 months old) of Camellia sasanqua 'Bonanza', Viburnum davidii, Viburnum tinus 'Spring Bouquet', Viburnum $\times$ pragense, and Rhododendron $\times$ 'Gloria' were rooted in 7.6-cm-diameter pots of Turface MVP (a fired montmorillonite clay soil conditioner, Profile Products LLC, Buffalo Grove, IL), and seeds of Camellia oleifera, C. sinensis, and Syringa vulgaris were germinated in 7.6-cm-diameter pots of turface; when plants had a well-developed root system, the roots were drenched with $15 \mathrm{ml}$ of a sporangial solution (approximately 6,000 sporangia/ml) of $P$. ramorum. All other plants were purchased as liners and their root systems washed of potting mix and transplanted into turface before the roots were drenched. Controls were 
drenched with distilled water and incubated along with inoculated plants under greenhouse conditions for a month; then root pieces were either washed and directly plated onto $\mathrm{P}_{5} \mathrm{ARP}$ media or surfacesterilized in $0.025 \%$ sodium hypochlorite ( $5 \mathrm{~min}$ for fine roots, $10 \mathrm{~min}$ for coarse roots) before plating (approximately 25 roots per plant were directly plated, and 25 were surface-sterilized before plating). Each species was inoculated as part of at least two batches of plants, with inoculum prepared separately, to ensure that root infection was replicable. All plants used in root inoculation experiments were known to be foliar hosts of $P$. ramorum except for Buxus sempervirens, which does not develop foliar symptoms in artificial inoculations (N. Shishkoff, unpublished data).

To study disease development on rooted cuttings, Viburnum tinus 'Spring Bouquet' was rooted in turface in "rhizotrons" made from petri plates (Fig. 1). A small portion of the bottom rim of the plate was removed to create a gap; then the plate was filled with turface, and the top and bottom were taped together. Stood on end, with the gap on top, these served as transparent pots, into which cuttings were inserted and allowed to root. Once roots were visible through the plastic sides, 5 to 10 chlamydospores from year-old sterile water culture were placed on $8 \times 8 \mathrm{~mm}$ squares of cellophane and stuck to the inside of one side of the petri plate at four different sites (Fig. 1). The behavior of chlamydospores and roots was then observed with a dissecting microscope over the next 2 weeks.

Statistical analysis. Data were analyzed using SAS version 9.1 (SAS Institute, Cary, NC). Survival of chlamydospores in sand or potting mix over time (percent recovery) was arcsine-transformed and analyzed using "PROC MIXED" (to separate the variances in soil and sand treatments) in order to estimate slopes for regression lines and contrast the treatments. Regression analysis was used to generate curves for survival over time of the pathogen in excised roots.

\section{RESULTS}

Surface sterilization with acidic electrolyzed water appeared to kill mycelium including hyaline swellings less than 1 month old, but after a month some mycelial structures appeared to survive treatment with AEW (Table 1). When round hyaline swellings interpreted to be immature chlamydospores from sterile water cultures aged 6 to 28 days were treated with AEW for 5, 10, 20, 30, or 40 min and then plated on $\mathrm{P}_{5} \mathrm{ARP}$, they generally did not produce colonies. Golden-colored chlamydospores from cultures 35 days or older produced colonies even after treatment with AEW. Chlamydospores from buried mesh bags also produced colonies after treatment with AEW (Table 2). The percent recovery from these samples treated with distilled water alone (1.4 to $88.8 \%$ ) did not much differ from recovery after treatment with AEW (1.0 to 28.2\%), suggesting that recovery in all treatments was of persistent structures. There was no evidence of stimulation of germination of chlamydospores after short exposure to AEW, as was seen with teliospores of Tilletia indica (5).

Buried mesh bag experiments showed that recovery of $P$. ramorum from potting mix or sand declined with time, but whether embedded in leaf tissue or buried as mycelium, it could be recovered after at least 334 days (the shortest experiment) at 11.1 to $11.9 \%$, and up to 654 days (the longest experiment) at 1.4 to $2.3 \%$ (Fig. 2). Chlamydospores plated on $\mathrm{P}_{5} \mathrm{ARP}$ were golden to brown in color, but highly refractive with dark field illumination. They germinated with multiple hyphal tips, and often produced sporangia immediately, later forming twiggy, highly refractive mycelium and young new chlamydospores. Germination generally occurred within the first 5 days of plating, and although plates were monitored for signs of later germination, no changes were observed after the first 2 weeks. Regression analysis of arcsine-transformed data showed a significant decrease in recovery over time $(P=0.0001)$, but there was not a significant treatment effect for chlamydospores versus leaf disks or sand versus potting mix. There was a trend $(P=0.12)$ toward greater survival of chlamydospores in leaf disks in sand, compared to leaf disks in potting mix (see Fig. 2B). This could be correlated with a noticeably greater preservation of the leaf tissue in sand, the more intact tissue perhaps protecting the chlamydospores.

$P$. ramorum was recovered from buried root pieces up to 341 days after burial. Detached roots were readily infected (62.3 to $97.2 \%$ at time 0 , in Table 3 ). After burial in potting mix, the recovery of $P$. ramorum from the dead roots declined to 0 to $27.5 \%$ after burial for approximately a year. In the first trial, survival was greatest in roots of

Table 1. Percent recovery of Phytophthora ramorum grown in sterile water culture after different periods of exposure to acidified electrolyzed water

\begin{tabular}{|c|c|c|c|c|c|c|}
\hline \multirow{2}{*}{$\begin{array}{l}\text { Age of culture } \\
\text { (days) }\end{array}$} & \multicolumn{6}{|c|}{ Exposure to acidified electrolyzed water $(\min )^{a}$} \\
\hline & $\mathbf{0}$ & 5 & 10 & 20 & 30 & 40 \\
\hline 6 & 88.8 & 0 & 0 & 0 & 0 & 0 \\
\hline 6 & 40.7 & 0 & 0 & 0 & 0 & 0 \\
\hline 7 & 91.7 & 0 & 0 & 0 & 0 & $\mathrm{ND}^{\mathrm{b}}$ \\
\hline 20 & 21.4 & 0 & 0 & 2.5 & 0 & 0 \\
\hline 21 & 22.7 & 0 & 0 & 0 & 1.4 & 0 \\
\hline 28 & 15.9 & 0 & 0 & 0 & 0 & 0 \\
\hline 35 & 27.6 & 14.9 & 8.7 & 2 & 22.9 & 4.6 \\
\hline 51 & 36 & 9 & 5.9 & 26.8 & 0 & ND \\
\hline 81 & 1.4 & 1.2 & 4.3 & 1.2 & 6.9 & 6.8 \\
\hline 88 & 29.7 & 1 & 2.7 & 3.8 & 0 & 7.6 \\
\hline 345 & 37.8 & 28.2 & 23.9 & 26.5 & 14.7 & 10.9 \\
\hline
\end{tabular}

a After exposure, chlamydospores (approximately 80 per treatment) were individually plated out on $\mathrm{P}_{5} \mathrm{ARP}$ selective medium.

${ }^{\mathrm{b}}$ Not determined.

Table 2. Percent recovery of Phytophthora ramorum from samples that had been buried in potting mix and then treated with acidified electrolyzed water

\begin{tabular}{lrrrrrr}
\hline & \multicolumn{7}{c}{ Exposure to acidified electrolyzed water (min) } \\
\cline { 2 - 7 } Days in soil & $\mathbf{0}$ & $\mathbf{5}$ & $\mathbf{1 0}$ & $\mathbf{2 0}$ & $\mathbf{3 0}$ & $\mathbf{4 0}$ \\
\hline $\begin{array}{l}\text { Chlamydospores in decayed } \\
\quad \text { plant tissue }\end{array}$ & & & & & & \\
143 & 36 & $\mathrm{ND}^{\mathrm{b}}$ & 16.6 & 1.3 & 22.1 & 26.1 \\
143 & 31.2 & $\mathrm{ND}$ & 30.6 & 8.9 & 28.8 & 20.4 \\
202 & 2.0 & 11.9 & 14.6 & 17.6 & 6.6 & $\mathrm{ND}$ \\
202 & 21.2 & 14.3 & 31.2 & 31.8 & 37 & $\mathrm{ND}$ \\
296 & 12.2 & 8.6 & 4.3 & 6.2 & 13 & 3.0 \\
& & & & & & \\
Chlamydospores from & & & & & & \\
sterile water culture & 53.3 & 43.6 & 43.5 & 37.5 & 17.1 & 16.5 \\
114 & 19.5 & 26.4 & 17.5 & 9.2 & 2.9 & 23.9 \\
145 & 1.4 & 0 & 0 & 5.6 & 1.3 & 2.3 \\
145 & 42.9 & 22.2 & 28.3 & 15.3 & 30.6 & 26.1 \\
222 & 18.9 & 27.2 & 16.2 & 19.1 & 12.5 & 5.0 \\
222 & 26.6 & 17.8 & 25.7 & 18.9 & 17.7 & 22.4 \\
334 & & &
\end{tabular}

a Samples were buried in potting mix (embedded in leaf tissue or as mycelium alone) then sampled after different amounts of time (see Fig. 2). Excess sample was exposed to acidified electrolyzed water, and then individual chlamydospores were plated on $\mathrm{P}_{5} \mathrm{ARP}$ selective medium.

${ }^{\mathrm{b}}$ Not determined. 

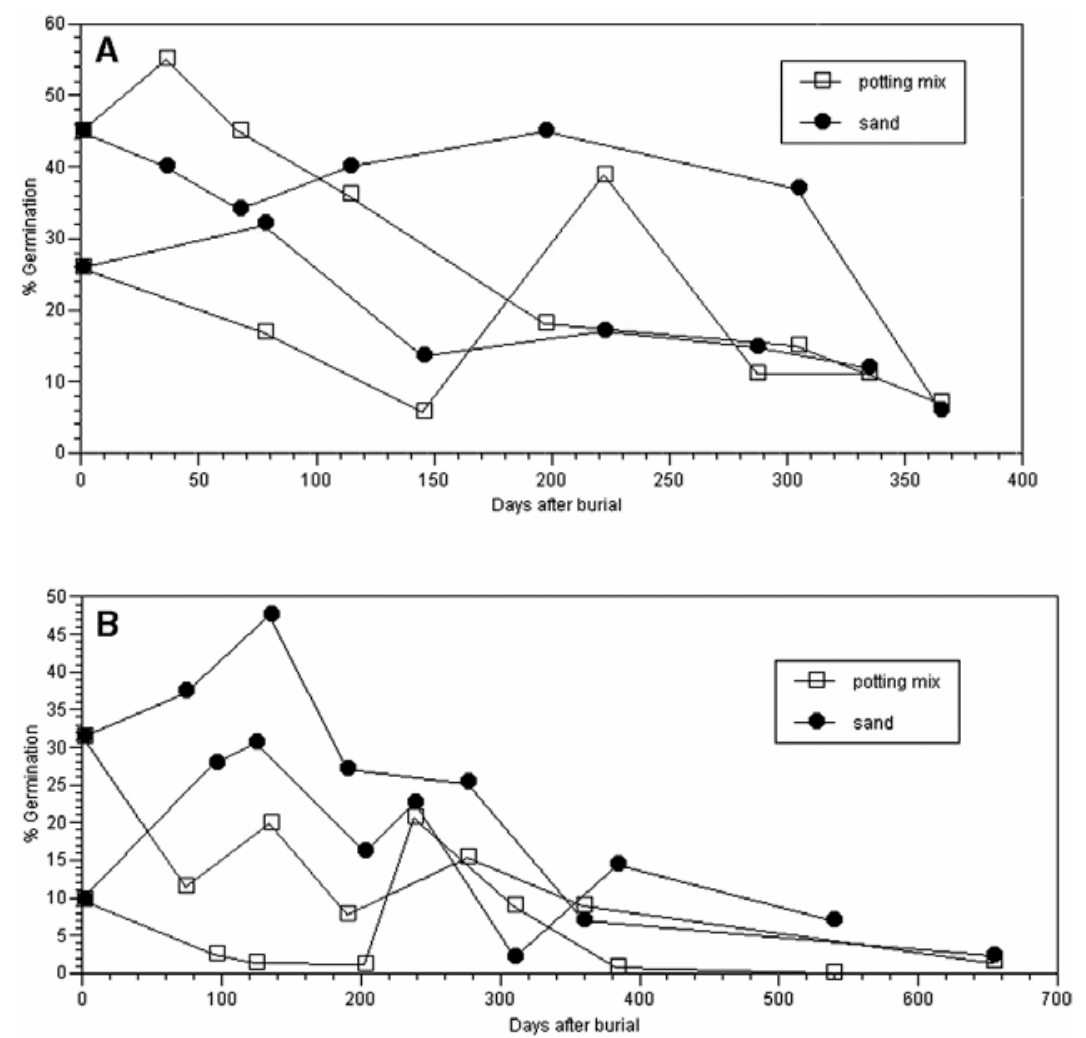

Fig. 2. Recovery of Phytophthora ramorum from mesh bags buried in either potting mix or pure sand. A, Mycelium including chlamydospores from sterile water culture. B, Leaf disks from infected Camellia containing embedded chlamydospores.

Table 3. Recovery of Phytophthora ramorum from inoculated root pieces buried in potting mix

\begin{tabular}{lcccc}
\hline Trial & $\begin{array}{c}\text { Days after } \\
\text { burial }\end{array}$ & $\begin{array}{c}\text { Viburnum } \\
\text { davidii }\end{array}$ & $\begin{array}{c}\text { Viburnum } \times \\
\text { pragense }\end{array}$ & $\begin{array}{c}\text { Syringa } \\
\text { vulgaris }\end{array}$ \\
\hline One & 0 & 79.3 & 81.8 & 62.3 \\
& 50 & 31.0 & 0.0 & 8.2 \\
& 101 & 5.4 & 12.1 & 10.8 \\
& 185 & 2.4 & 0.0 & 0.0 \\
Two & 255 & 0.6 & 2.9 & 0.0 \\
& 341 & 5.2 & 0.0 & 0.0 \\
& 0 & 91.5 & 97.2 & 96.3 \\
& 39 & 6.1 & 6.2 & 27.4 \\
& 89 & 4.9 & 0.0 & 16.7 \\
& 147 & 0.0 & 1.0 & 29.7 \\
\hline
\end{tabular}

V. davidii, which also showed the least disintegration: epidermis, cortex, and vascular stele were easily recognizable at the end of the study period. In the second trial, however, survival was greatest in lilac roots, which were the most delicate. Recovery was quite variable; regression analysis showed that, in four of the six trials analyzed (three root types, two trials each), there was a significant decline in pathogen survival over time $(P<0.05)$, but in the two other trials, the data did not show a relationship with time.

Root infection was observed in all plants tested except Lonicera hispidula and Buxus sempervirens (Table 4). In hosts that became infected, recovery was from both washed and surface-sterilized roots, suggesting that the roots, while symptomless, were internally infected.

When chlamydospores were placed near roots of Viburnum tinus in petri plate "rhizotrons", sporangia were seen to develop from chlamydospores after 3 to 5 days; sometimes zoospores were evident. By 10 days, the tips of some roots were infected by $P$. ramorum, and dozens of sporangia were visible on the surface of root tips.

\section{DISCUSSION}

$P$. ramorum persisted in potting mix for many months, whether embedded in plant leaf tissue or alone as mycelium. It survived up to 654 days, albeit at very low levels (1.4 to $2.3 \%$ ) in this study; in subsequent studies, it was shown that in soils artificially infested with chlamydospores and assayed for 4 months, decline was rapid at $22^{\circ} \mathrm{C}$, but undetectable at $4^{\circ} \mathrm{C}(6)$. In this study, chlamydospores were selectively plated, but that doesn't mean hyphal fragments didn't also survive. Evidence of treatment with AEW, however, suggested that hyphae had largely disappeared.

Germinating chlamydospores were clearly still alive, but the nongermination of others said nothing about their state. It

Table 4. Recovery of Phytophthora ramorum onto plates of $\mathrm{P}_{5} \mathrm{ARP}$ from washed or surface-sterilized roots of plants approximately 1 month after inoculation with a root drench of sporangia

\begin{tabular}{|c|c|c|c|c|c|}
\hline Plant species $^{\mathbf{a}}$ & $\begin{array}{l}\text { Common name } \\
\text { or cultivar }\end{array}$ & $\begin{array}{l}\text { No. plants } \\
\text { inoculated }\end{array}$ & $\begin{array}{l}\text { No. plants } \\
\text { infected }\end{array}$ & $\begin{array}{c}\% \text { Washed } \\
\text { roots infected }\end{array}$ & $\begin{array}{l}\% \text { Surface- } \\
\text { sterilized roots } \\
\text { infected }^{\mathbf{b}}\end{array}$ \\
\hline Acer macrophyllum & Bigleaf maple & 12 & 2 & 0.3 & 0.8 \\
\hline Buxus sempervirens & 'Graham Blandy' & 5 & 0 & 0.0 & 0.0 \\
\hline Camellia oleifera & Tea-oil camellia & 15 & 10 & 21.6 & 5.3 \\
\hline Camellia sasanqua & 'Bonanza' & 10 & 6 & 29.2 & 13.8 \\
\hline Camellia sinensis var. sinensis & Small-leafed tea & 8 & 7 & 15.0 & 6.0 \\
\hline Lonicera hispidula & Hairy honeysuckle & 9 & 0 & 0.0 & 0.0 \\
\hline Rhododendron $\times$ & 'Gloria' & 10 & 9 & 16.0 & 17.10 \\
\hline Syringa vulgaris & Common lilac & 15 & 9 & 14.0 & 8.0 \\
\hline Taxus baccata & Yew 'fastigiata' & 5 & 2 & 10.2 & 10.2 \\
\hline Umbellularia californica & California bay laurel & 6 & 5 & 16.9 & 7.1 \\
\hline Vaccinium macrocarpon & Bog cranberry & 7 & 3 & 0.4 & 5.2 \\
\hline Viburnum davidii & David's viburnum & 15 & 10 & 8.0 & 2.0 \\
\hline Viburnum tinus & 'Spring Bouquet' & 14 & 12 & 28.7 & 27.2 \\
\hline Viburnum $\times$ pragense & 'Decker' & 10 & 8 & 24.0 & 16.0 \\
\hline
\end{tabular}

a All species listed are known to be foliar hosts of P. ramorum except Buxus sempervirens, which has unknown status.

${ }^{\mathrm{b}}$ Roots were either washed or surface-sterilized for 5 to $10 \mathrm{~min}$ in $0.025 \%$ sodium hypochlorite before being plated on $\mathrm{P}_{5} \mathrm{ARP}$ selective media. 
wasn't certain whether the nongerminating spores were dead but undecayed and still recognizable, or whether they were inhibited from germinating. There is evidence that in buried leaf tissue exposed to dry conditions, recovery of $P$. ramorum was difficult without a hydration treatment (9).

$P$. ramorum could persist in soil in dead root tissue for at least 8 to 11 months. Dissection of roots under a dissecting microscope did not reveal the obvious presence of chlamydospores. Therefore, it was unclear in what form the pathogen was surviving: as hyphae or chlamydospores. $P$. cinnamomi is known to persist at least 6 months in dead roots in soil (13).

$P$. ramorum could infect living roots and persist on these roots for at least a month. The sporangial suspension used to inoculate roots was high $(15 \mathrm{ml}$ of a suspension containing 6,000 sporangia/ml), and might not represent a "natural" dose. However, in other work, infected lilac leaf pieces placed on the surface of potting mix were determined, at time 0 , to give off an average of 6,000 sporangia per square inch of lesion per day, sometimes exceeding 10,000 per square inch (N. Shishkoff, unpublished data), suggesting that high sporangial doses under nursery conditions are possible. In addition, these studies were done to show that infection could occur, not to look at natural conditions. This infection of the roots of foliar hosts appeared to be internal as well as superficial, since the pathogen could be recovered from surface-sterilized root. In other work comparing root infection in plants that showed foliar symptoms with those that didn't (14), it was observed that plants that did not show foliar symptoms had low levels of recovery of $P$. ramorum from surfacesterilized roots, while plants that were foliar hosts showed significant recovery of the pathogen from surface-sterilized roots. In some host plants, such as Rhododendron, inoculation of the roots has led not only to internal infection, but also to systemic infection via the xylem to aboveground parts (12). It's possible that in at least some hosts, an invisible root infection could develop, months later, into aboveground symptoms. In one instance, asymptomatic rhododendrons in California were subsequently observed to have foliar and stem symptoms (4). If root-infected plants were shipped to other states and then developed aboveground symptoms, they might be able to spread the disease to surrounding plants. It is not yet clear whether the roots of some host plants could be infected without systemic spread to aboveground parts, and whether such plants could serve as inoculum sources, but given the sporulation observed on infected Viburnum roots, it is possible that detached sporangia or zoospores could move out of pots with irrigation.

These facts, taken together, suggest a soil phase exists for $P$. ramorum. The chlamydospores can persist in soil and dead roots, infect living plant roots, and form sporangia on root tissue. Further research is needed on $P$. ramorum and its soil phase to develop methods to prevent its spread on containerized nursery plants and to better understand the potential threat the organism poses to forest ecosystems.

\section{ACKNOWLEDGMENTS}

I thank John Phillips for help with statistical analyses.

\section{LITERATURE CITED}

1. Anagnostakis, S. L. 2001. The effect of importations of pests and pathogens on a native tree. Biol. Invasions 3:245-254.

2. Animal and Plant Health Inspection Service. 2007. 7 CFR Part 301. Federal Register Vol. 72, No. 38.

3. Balci, Y., Balci, S., Eggers, J., MacDonald, W., Juzwik, J., Long, R., and Gottschalk, K. 2005. Occurrence of Phytophthora species in central and eastern U.S. oak ecosystems. (Abstr.) Phytopathology 95:960.

4. Bienapfl, J., Zanzot, J., Murphy, S., Garbelotto, M., and Rizzo, D. 2005. Isolation of a new lineage of Phytophthora ramorum from asymptomatic stems and roots of a commercial lot of rhododendron in California. (Abstr.) Phytopathology 95:S9.

5. Bonde, M. R., Nester, S. E., Khayat, A., Smilanick, J. L., Frederick, R. D., and Schaad, N. W. 1999. Comparison of effects of acidic electrolyzed water and $\mathrm{NaOCl}$ on Tilletia indica teliospore germination. Plant Dis. 83:627-632.
6. Colburn, G., and Shishkoff, N. 2005. Survivability and pathogenicity of Phytophthora ramorum chlamydospores in soil. (Abstr.) Phytopathology 95:S20.

7. Davidson, J. M., Werres, S., Garbelotto, M., Hansen, E. M., and Rizzo, D. M. 2003. Sudden oak death and associated diseases caused by Phytophthora ramorum. Online. Plant Health Progress doi:10.1094/PHP-2003-0707-01-DG.

8. Davidson, J. M., Wickland, A. C., Patterson, H. A., Falk, K. R., and Rizzo, D. M. 2005. Transmission of Phytophthora ramorum in mixed-evergreen forest in California. Phytopathology 95:587-596.

9. Fichtner, E., Lynch, S., and Rizzo, D. 2005. Seasonal survival of Phytophthora ramorum in soils. (Abstr.) Phytopathology 95:S29.

10. Hwang, S. C., and Ko, W. L. 1977. Biology of chlamydospores, sporangia, and zoospores of Phytophthora cinnamomi in soil. Phytopathology 68:726-731.

11. Jeffers, S. N., and Martin, S. B. 1986. Comparison of two media selective for Phytophthora and Pythium species. Plant Dis. 70:1038-1043.

12. Lewis, C. D., Roth, M. L., Chouquette, C. J., and Parke, J. L. 2004. Root infection of rhododendron by Phytophthora ramorum. (Abstr.) Phytopathology 94:S60.

13. Mackay, A., Weste, G., and Sharpe, K. 1985. Survival of Phytophthora cinnamomi in buried Eucalyptus roots. Phytopathol. Z. 114:214 223.

14. Newhook, F. J., and Podger, F. D. 1972. The role of Phytophthora cinnamomi in Australian and New Zealand forests. Annu. Rev. Phytopathol. 10:299-326.

15. Parke, J. L., Bienapfl, E. Oh., Rizzo, D., Hansen, E., Buckles, G., Lee, C., and Valachovic, Y. 2006. Natural infection of tanoak seedling roots by Phytophthora ramorum. (Abstr.) Phytopathology 96:S90.

16. Shishkoff, N., and Senesac, A. 2005. Susceptibility to Phytophthora ramorum of roots and shoots of common container weeds. (Abstr.) Phytopathology 95:S96.

17. Shishkoff, N., and Tooley, P. 2004. Persistence of Phytophthora ramorum in nursery plants and soil. (Abstr.) Phytopathology 94:S95.

18. Tubajika, K. M., Bulluck, R., Shiel, P. J., Scott, S. E., and Sawyer, A. J. 2006. The occurrence of Phytophthora ramorum in nursery stock in California, Oregon, and Washington states. Online. Plant Health Progress doi:10.1094/PHP-2006-0315-02-RS.

19. Werres, S., Marwitz, R., Man In't Veld, W., De Cock, A. W. A. M., Bonants, P. J. M., De Weerdt, M., Themann, K., Ilieva, E., and Baayen, R. P. 2001. Phytophthora ramorum sp. nov., a new pathogen on Rhododendron and Viburnum. Mycol. Res. 105(10):1155-1165. 